\title{
SISTEM KEKERABATAN \\ DALAM KEBUDAYAAN MINANGKABAU: PERSPEKTIF ALIRAN FILSAFAT STRUKTURALISME JEAN CLAUDE LEVI-STRAUSS
}

\section{Misnal Munir}

Fakultas Filsafat, Universitas Gadjah Mada, Yogyakarta

Email:misnalmunir@ugm.ac.id

\begin{abstract}
Abstrak
Kebudayaan Minangkabau adalah satu kebudayaan yang masih menganut sistem kekerabatan yang berdasarkan pada asas matrilineal hingga saat ini. Artikel ini bertujuan untuk memahami hubungan kekerabatan dalam kebudayaan Minangkabau berdasarkan teori Strukturalisme antropologis Levi-Strauss. Sistem kekerabatan dalam kebudayaan Minangkabau, menurut perspektif Strukturalisme Levi-Strauss, menempatkan laki-laki sebagai sarana komunikasi antarklen atau suku. Kebudayaan Minangkabau yang menganut sistem matrilineal menempatkan perempuan sebagai pihak yang menetap, sedangkan laki-laki sebagai pihak yang mendatangi rumah perempuan. Sistem kekerabatan matrilineal ini menempatkan perempuan sebagai pewaris harta kekayaan, dan laki-laki sebagai pihak yang berpindah ke rumah perempuan.
\end{abstract}

Kata kunci:kekerabatan, matrilineal, klen.

\section{Abstract}

The culture of Minangkabau is one culture that embraces the matrilineal kinship system until now. This article aims to comprehend a kinship relation in the culture of Minangkabau based on the anthropological structuralism theory of Levi-Strauss. The kinship system of the culture of Minangkabau, according to the structuralism perspective of Levi-Strauss, places a man as a medium in communicating among clans or tribes. The matrilineal system of the culture of Minangkabau places a woman as a remaining side, while a man as a visiting side to woman house. The matrilineal system places a woman as a heritant of wealth and a man as a person who move to woman house.

Keywords: kinship, matrilineal, clan.

\section{PENDAHULUAN}

Manusia adalah makhluk sosial yang selalu berinteraksi dengan sesamanya. Manusia dalam hidupnya tidak hanya membutuhkan ke- 
beradaan manusia lainnya, lebih dari itu manusia menjalin hubungan dengan sesamanya dalam berbagai bentuk ikatan. Salah satu bentuk ikatan hubungan itu ialah perkawinan.

Perkawinan pada hakikatnya tidak hanya menghubungkan antara laki-laki dan perempuan dalam ikatan formal yang disebut keluarga. Perkawinan, namun demikian, juga mempertalikan antara pihak keluarga laki-laki dan perempuan. Perkawinan, bahkan lebih luas lagi, menghubungkan antara dua kelompok besar yang disebut dengan klen atau suku.

Perkawinan sebagai bentuk ikatan antara manusia yang satu dengan manusia yang lain, yang menghubungkan antara individu yang satu dengan individu yang lain, dan antara kelompok yang satu dengan kelompok yang lain, yang memiliki aturan yang baku. Setiap orang dan kelompok harus mematuhi aturan tersebut. Adanya aturan yang harus dipatuhi dalam hubungan antar individu dan kelompok menjadi bahan studi bagi aliran filsafat Strukturalisme. Strukturalisme adalah aliran filsafat yang menyelidiki pola-pola dasar yang tetap (pattern) dalam bahasa-bahasa, agama-agama, sistem-sistem ekonomi dan politik, serta dalam karya-karya kesusasteraan (Mudhofir, 1988: 92). Aturan baku yang unik, khususnya dalam perkawinan, nampak pada kebudayaan Minangkabau dan ini menarik untuk dikaji dalam perspektif filsafat Strukturalisme.

Kebudayaan Minangkabau adalah suatu bentuk kebudayaan yang strukturnya unik. Apabila kebanyakan kebudayaan menganut sistem patrilineal dalam kekerabatannya, maka kebudayaan Minangkabau menganut sistem matrilineal. Nenek moyang orang Minang sudah berketetapan hati untuk menghitung garis keturunannya berdasarkan garis keturunan ibu. Sistem kekerabatan itu sulit dibantah karena sistem ini merupakan dalil yang sudah hidup, tumbuh dan berkembang di Minangkabau.

Asas sistem kekerabatan matrilineal di Minangkabau ini mengandung 7 ciri kekerabatan, yaitu: 1) Garis keturunan dihitung menurut garis keturunan ibu; 2) Suku anak menurut suku ibu, Basuku kabakeh ibu, Babangso kabakeh ayah. Jauah mancari suku dakek mancari ibu, Tabang 
basitumpu Hinggok mancakam; 3) Pusako tinggi turun dari mamak ka kamanakan, pusako randah turun dari bapak kapado anak. Dalam hal ini terjadi "ganggam bauntuak", hak kuasa pada perempuan, hak memelihara kepada laki-laki.

Berdasar pada keunikan sistem kekerabatan Minangkabau tersebut, artikel ini akan memusatkan pembahasan pada beberapa pertanyaan pokok, yaitu: (a) Apa konsep Levi-Strauss tentang sistem kekerabatan? (b) Apa konsep kekerabatan menurut kebudayaan Minangkabau? (c). Bagaimanakah corak hubungan kekerabatan dalam kebudayaan Minangkabau dilihat dari perspektif filsafat Strukturalisme Levi-Strauss?

\section{PENGERTIAN STRUKTURALISME}

Jika seseorang hendak mempelajari Strukturalisme maka segera akan terbentur pada berbagai kesulitan. Ini karena dalam kalangan ilmiah istilah "struktur" dan "Strukturalisme" banyak dipakai dan tidak selalu dalam arti yang sama. Istilah-istilah itu dipakai dalam bidang matematika, logika, fisika, biologi, psikologi, sosiologi, ilmu bahasa, dan ilmu-ilmu kemanusiaan lainnya (Bertens, 2001: 176). Kesulitan lain yang tidak kalah rumitnya ialah dalam hal menentukan apakah seorang tokoh yang memakai metode struktural dapat dikatakan sebagai strukturalis, atau apakah ia seorang pengikut aliran filsafat Strukturalisme? Kenyataannya, sebagian dari mereka yang berpikir dengan gaya Strukturalisme ini tidak merasa senang disebut sebagai seorang strukturalis. Bahkan ada di antara mereka yang menolak secara tegas sebutan strukturalis.

Untuk mengatasi kesulitan tersebut, dalam artikel ini istilah Strukturalisme akan dibatasi dengan dua pengertian pokok yang sangat erat kaitannya dengan Strukturalisme sebagai aliran filsafat. Pertama, Strukturalisme adalah metode atau metodologi yang digunakan untuk mempelajari ilmu-ilmu kemanusiaan dengan bertitik tolak dari prinsip-prinsip linguistik yang dirintis oleh Ferdinand de Saussure. Di sini ilmu-ilmu kemanusiaan dimaksudkan sebagai ilmu-ilmu yang dalam terminologi Dilthey disebut Geisteswissenschaften, yang dibedakan 
dari ilmu-ilmu pengetahuan alam atau Naturwissenschaften. Kedua, Strukturalisme merupakan suatu aliran filsafat yang hendak memahami sejumlah masalah yang muncul dalam sejarah filsafat. Di sini metodologi struktural dipakai untuk membahas manusia, sejarah, kebudayaan, serta hubungan antara kebudayaan dan alam, yaitu dengan membuka secara sistematik struktur-struktur mental universal yang memanifestasikan dirinya dalam struktur-struktur kekerabatan dan struktur-struktur sosial yang lebih luas, dalam kesusasteraan dan dalam pola-pola psikologik tak sadar yang menggerakkan tindakan manusia (Kurzwell, 1980: vi-x).

Dari uraian di atas, pengertian Strukturalisme yang pertama mempunyai dimensi epistemologik. Aliran filsafat Strukturalisme pada pengertian pertama ingin memberikan status ilmiah pada ilmu-ilmu kemanusiaan. Sedangkan pengertian Strukturalisme yang kedua lebih bersifat mazhab atau aliran yang berusaha menerapkan metode struktural dalam berbagai bidang ilmu. Pengertian Strukturalisme yang kedua ini mempunyai dampak yang lebih luas sehingga melahirkan berbagai macam bentuk dan corak filsafat Strukturalisme.

Secara umum juga dapat dikatakan bahwa Strukturalisme merupakan aliran dalam filsafat, linguistik, psikiatri, fenomenologi agama, ekonomi dan politik. Pada pemahaman tersebut, Strukturalisme menyelidiki pola-pola dasar yang tetap (pattern) dalam bahasa-bahasa, agama-agama, sistem-sistem ekonomi dan politik, serta dalam karyakarya kesusasteraan (Mudhofir, 1988: 92). Manusia diselidiki sebagai unsur yang berfungsi dalam berbagai struktur bawah sadar, strukturstruktur politik, sosial dan ekonomi. Manusia dibicarakan sebagai roda kecil dalam suatu mekanisme otonom, yang lebih otonom dari manusia itu sendiri. Fungsi manusia dalam keseluruhan struktur dibandingkan dengan fungsi kata dalam suatu teks. Manusia tidak berbicara sebagai subyek, melainkan lebih dibicarakan. Manusia sebagai makhluk historis dan sebagai subyek bebas yang menjadi tema pokok dalam filsafat eksistensialisme tidak muncul dalam filsafat Strukturalisme. Manusia digambarkan sebagai "hasil" struktur-struktur, dan tidak lagi sebagai "pencipta" struktur-strukturitu. 


\section{LATAR BELAKANG STRUKTURALISME}

Pangkal tolak dari aliran filsafat Strukturalisme adalah teori tentang bahasa, khususnya teori linguistik modern yang dipelopori oleh Ferdinand de Saussure (1957-1913), seorang linguis berkebangsaan Swedia. Karir akademisnya diawali dengan mengajar di Paris, dan akhirnya menjadi professor di Jenewa, kota tempat ia mendirikan Mazhab Jenewa. Selama hidupnya Saussure hanya mempublikasikan sedikit karangan, sedangkan buku yang membuat namanya menjadi terkenal di bidang linguistik diterbitkan oleh murid-muridnya dengan judul Cours de Linguistique Generale (Kursus Tentang Linguistik Umum) yang diterbitkan pada tahun 1916. Beberapa prinsip yang digunakan oleh para penganut aliran filsafat Strukturalisme berasal dari buku tersebut.

Hal yang sangat penting dari teori tentang bahasa dan mempunyai peranan besar dalam aliran filsafat Strukturalisme seperti yang diuraikan dalam buku Saussure itu ialah masalah distingsi (pembedaan) atas beberapa hal, yaitu: signifiant dan signifie, kemudian langage, parole, dan langue, serta sinkroni dan diakroni (Bertens, 2001:179).

\section{Signifiant dan signifie}

Pembedaan ini merupakan inti pandangan Saussure tentang tanda. Menurut pandangan populer, suatu tanda bahasa menunjuk kepada benda dalam realitas. Kata 'pohon' misalnya menunjuk kepada pohon Flamboyan yang berdiri di situ. Pendapat ini ditolak oleh Saussure. Menurutnya, suatu tanda bahasa bermakna bukan karena referensinya kepada benda dalam realitas, sebab yang ditandakan dalam tanda bahasa bukan benda, melainkan konsep tentang benda (Bertens, 2001: 180).

Untuk menerangkan pendapat tersebut di atas, Saussure mengatakan bahwa tanda bahasa yang dipelajari oleh linguistik terdiri dari 2 unsur, yaitu: le signifiant dan le signifie. Dalam bahasa Indonesia dapat diterjemahkan "penanda" ("yang menandakan") dan "yang ditandakan". Signifiant adalah bunyi yang bermakna atau coretan yang ber- 
makna. Dengan demikian, signifiant adalah aspek material dari bahasa yang berupa apa yang dikatakan atau didengar, dan apa yang ditulis atau dibaca. Sedangkan signifie adalah gambaran mental, konsep, atau pikiran. Artinya, signifie adalah aspek mental dari bahasa (Bertens, 2001: 181).

Kedua pembeda tanda bahasa tersebut di atas (signifiant dan signifie) hanya dapat dibedakan, akan tetapi tidak dapat dipisahkan dalam pemakaiannya. Setiap tanda selalu terdiri atas dua hal itu. Suatu signifiant (penanda) tanpa signifie (yang ditandakan) tidak mempunyai arti apa-apa (tidak bermakna) sebab suatu "penanda" yang tidak memiliki unsur "yang ditandakan" bukanlah tanda bahasa. Sebaliknya, suatu signifie (yang ditandakan) tidak mungkin dapat disampaikan atau ditangkap lepas dari signifiant (penanda) sebab yang ditandakan termasuk tanda itu sendiri. Oleh karena itu, menurut Saussure, signifiant dan signifie merupakan satu kesatuan. Keduanya (signifiant dan signifie) ibarat dua sisi dari sehelai kertas.

\section{Langage, langue, dan parole}

Langage, langue, dan parole merupakan istilah yang terdapat dalam bahasa Perancis yang digunakan oleh Saussure. Ketiga istilah tersebut sulit diterjemahkan ke dalam bahasa lain. Langage mengacu pada pengertian fenomena bahasa secara umum. Langage terdiri atas 2 bagian, yaitu: langue dan parole. Langue mengacu pada pengertian bahasa sejauh merupakan milik bersama dari suatu golongan bahasa tertentu. Sedangkan pengertian parole mengacu pada pemakaian bahasa yang individual, yang dalam bahasa Inggris diterjemahkan dengan speech atau language use (percakapan atau penggunaan bahasa) (Bertens, 2001: 182). Dalam linguistik yang menyelidiki bahasa, yang menjadi obyek penyelidikan adalah langue, yaitu: bahasa sebagai milik bersama dari suatu kelompok yang menggunakannya.

Saussure mengemukakan, langue itu harus dianggap sebagai suatu sistem (Bertens, 2001: 183). Untuk menjelaskan bahasa sebagai suatu sistem yang ditunjuk oleh istilah langue itu, Saussure membandingkannya dengan main catur. Seseorang, untuk mengerti main catur, tidak 
perlu mengetahui tentang asal-usul permainan tersebut, dan tidak perlu mempersoalkan bahan dari buah-buah catur tersebut, karena hal itu tidak relevan, dan tidak akan memberikan sumbangan apapun terhadap permainan catur tersebut. Yang perlu diketahui dari permainan tersebut ialah aturan-aturan yang mengonstituasi sistem permainannya. Menambah atau mengurangi jumlah buah catur berarti mengubah sistem secara esensial, atau mengubah aturan pergerakan kuda akan mengubah semua sistem permainan.

Demikian juga halnya dengan bahasa. Menurut Saussure, yang penting dalam bahasa ialah aturan-aturan yang mengkonstituirnya, susunan unsur-unsurnya dalam hubungan satu sama lain, serta relasirelasi dan oposisi-oposisi yang membentuk sistem itu. Sebagaimana halnya dengan permainan catur seperti yang dicontohkan di atas, bahasa juga merupakan keseluruhan sistematis yang terdiri dari unsurunsur yang masing-masing mempunyai fungsinya sendiri. Perubahan terhadap salah satu unsur atau aturan bahasa akan mengubah juga seluruh sistem yang berlaku pada bahasa yang bersangkutan.

Meskipun dalam linguistik yang menjadi obyek penelitian bahasa adalah langue, tidak berarti parole sebagai bahasa pada sisi yang lain tidak mempunyai peranan sama sekali. Kedua hal tersebut saling menentukan dan memiliki ketergantungan. Ketergantungan antara langue dan parole dalam suatu hubungan, dijelaskan oleh Saussure sebagai berikut:

"Language is necessary if speaking is to be intelligible and produce its all effects; but speaking is necessary for establishment of language, and historically its actuality always comes first .... Speaking is what causes language to evolve; impressions gathered from listening to others modify our linguistic habits. Language and speaking (langage and parole) are then interdependent; the former is both the instrument and the product of the latter" (Wittig, 1975:22).

Bahasa itu perlu jika (kegiatan) berbicara dapat dimengerti dan menghasilkan segala akibatnya; namun (kegiatan) berbicara perlu bagi terbentuknya bahasa, dan secara historis (kegiatan) berbicara selalu muncul pertama .... (Kegiatan) 
berbicara adalah hal yang menyebabkan bahasa berkembang; kesan-kesan yang dikumpulkan dari menyimak orang lain mengubah kebiasaan berbahasa kita. Bahasa dan (kegiatan) berbicara (langage dan parole) kemudian saling tergantung; yang pertama (language) adalah instrumen dan sekaligus hasil dari yang terakhir (kegiatan berbicara).

Bahasa sebagai suatu sistem (langue) yang merupakan aspek sosial dari ucapan, keseluruhan bayangan kata yang dijadikan satu dalam pikiran beberapa orang yang berbicara dalam bahasa yang sama, tidak dapat melepaskan pengaruhnya dari parole, yaitu aktualisasi bahasa yang muncul dari pemakai bahasa bersangkutan. Kegiatan berbicara atau dapat juga disebut dengan bahasa lisan biasanya muncul lebih dahulu dari bahasa tulisan yang biasanya sangat terikat oleh sistem. Oleh karena itu bahasa lisan (parole) sering mengubah bahasa tulisan (lang$u$ ), dan bahasa itu akan mengalami perkembangan yang terus-menerus.

\section{Sinkroni dan diakroni}

Bahasa sebagai suatu sistem dapat dipelajari menurut 2 sudut pandang, yaitu: sinkroni dan diakroni. Kedua istilah tersebut berasal dari kata Yunani, khronos yang berarti 'waktu', ditambah awalan syn dan dia, masing-masing berarti 'bersama' dan 'melalui'. Secara singkat dapat dijelaskan bahwa, sinkroni adalah "bertepatan menurut waktu" dan diakroni adalah "menelusuri waktu" (Bertens, 2001: 185). Jika diterapkan dalam bidang bahasa, makna sinkroni adalah penyelidikan tentang bahasa yang sama sekali lepas dari perspektif historis. Artinya, sinkroni adalah peninjauan yang sifatnya ahistoris, sedangkan diakroni berusaha melakukan penyelidikan terhadap bahasa dari tinjauan historis.

Para penyelidik bahasa sebelum Saussure (kaum linguis) mempelajari bahasa dari sudut pandang diakroni. Mereka mempelajari bahasa dari sudut pandang komparatif-historis dengan menelusuri proses evolusi bahasa-bahasa tertentu, etimologi, perubahan fonetis, dan lain sebagainya, namun mengabaikan sudut pandang sinkroni. Hal itu ditentang oleh Saussure. Menurutnya, yang terpenting dari penye- 
lidikan tentang bahasa adalah melalui sudut pandang sinkroni sebab bahasa bagi Saussure adalah suatu sistem. Oleh karena itu, linguistik harus mempelajari sistem bahasa sebagaimana dipakai sekarang ini, dengan tidak memperdulikan perkembangan-perkembangan dan perubahan-perubahan yang telah menghasilkan sistem itu.

Meskipun Saussure mengesampingkan mengenyampingkan semua penyelidikan yang bersifat ekstralingual, yang terlepas sama sekali dari dimensi waktu, tidak berarti ia menolak sama sekali penyelidikan bahasa dari sudut pandang diakroni. Ia hanya menekankan bahwa penyelidikan sinkronis harus mendahului penyelidikan diakronis. Penyelidikan diakronis hanya dipakai sejauh hal itu bersifat membandingkan bahasa-bahasa sebagai sistem-sistem. Tidak ada gunanya mempelajari evolusi atau perkembangan salah satu unsur bahasa, terlepas dari sistem-sistem di mana unsur itu berfungsi.

Untuk menunjukkan distingsi antara sinkroni dan diakroni, serta pentingnya sudut pandang sinkroni dalam bahasa, ia memakai perumpamaan "raja" dalam permainan catur. Menurut Saussure, "raja" catur dapat diterangkan secara diakronik begitu saja, tanpa didasarkan atas pikiran-pikiran tentang terciptanya permainan ini, atau langkah-langkah yang terjadi sebelumnya hingga sampai pada formasi tertentu. Demikian juga halnya dengan bahasa. Setiap bahasa selalu berubah dan berkembang, tidak terpaku pada satu saat dan pada bentuk-bentuk tertentu. Jadi, studi tentang bahasa selalu diawali dengan realitas bahasa yang dipakai secara umum, sebelum melakukan studi tentang asal mula pembentukannya.

Pandangan Saussure telah membuka jalan bagi suatu studi tentang bahasa yang kemudian disebut "struktural", yang disebut juga "linguistik struktural". Prinsip-prinsip linguistik tersebut menjadi dasar bagi para penganut aliran filsafat Strukturalisme. Dengan kata lain, para strukturalis filosofis mendasarkan filsafatnya pada Strukturalisme linguistik yang telah dirintis oleh Fardinand de Saussure.

Dengan diterapkannya metode struktural ke dalam bidang-bidang lain di luar studi bahasa, maka Strukturalisme telah menjadi gerakan yang jauh lebih luas. Yang menarik ialah bahwa Saussure sen- 
diri telah meramalkan timbulnya suatu ilmu baru yang menerapkan metode linguistik struktural atas wilayah-wilayah sosial lain dari bahasa. Ilmu itu disebutnya dengan "semiologi", dan ilmu bahasa hanya merupakan sebuah cabang dari semiologi itu (Bertens, 2001: 188). Lebih lanjut dalam buku Cours de Linguistique Generale, Saussure mengatakan:

"Language is a sistem of signs which express ideas. Hence it is like writing, the deaf and dumb alphabeth, symbolic rites, etiquette, military signals and so on, except that it is the most important of such sistems. One may therefore envisage a science which studies the life of signs in the framework of social life .... We shall call it semiologi (from the Greek semeion, 'sign'). It will teach us what signs consist of, the laws by which they are governed" (Schiwy, 1986: 170).

Bahasa adalah suatu sistem tanda-tanda yang mengekspresikan ide-ide. Maka dari itu bahasa menyerupai tulisan, abjad untuk orang bisu/tuli, ritus-ritus simbolis, etiket, sinyal-sinyal militer, dan seterusnya; hanya harus ditambah, bahasa adalah yang paling penting di antara sistemsistem semacam itu. Karena itu orang dapat membayangkan suatu ilmu yang mempelajari kehidupan tanda-tanda dalam kerangka kerja kehidupan sosial .... Kita menyebutnya "semiologi" (dari bahasa Yunani semeion, yang artinya "tanda"). Ilmu itu akan mengajarkan kepada kita tandatanda itu terdiri dari apa dan hukum-hukum yang mempengaruhinya.

\section{STRUKTURALISME CLAUDE LEVI-STRAUSS}

Claude Levi-Strauss, pemikir Perancis berdarah Yahudi, adalah orang yang namanya tidak dapat dipisahkan dari aliran filsafat Strukturalisme. Melalui karya-karyanya, Strukturalisme menjadi suatu aliran yang mendapatkan suatu tempat tersendiri dalam dunia filsafat. 
Karya Levi-Strauss yang membuat namanya begitu erat dikaitkan dengan Strukturalisme, yaitu: Les Structures Elementaires de la Parente (Struktur-struktur Elementer Kekerabatan). Dalam buku ini LeviStrauss berusaha menganalisis dan menjelaskan sistem-sistem kekerabatan primitif dengan memakai metode strukturalis.

Sebelum membicarakan teori Strukturalisme Levi-Strauss, akan lebih baik jika membicarakan sejarah hidup Levi-Strauss secara singkat. Hal ini penting mengingat perjalanan hidup penggagas teori antropologi struktural ini sangat dinamis. Latar belakang pendidikan, pengalaman kerja dan pola pikirnya sangat menentukan dalam apa yang dicetuskan dalam teori strukturalnya. Selain itu, yang juga sangat menentukan dalam pandangan-pandangan Levi-Strauss adalah hubungannya dengan para pakar berbagai bidang di Brazil, Perancis maupun saat ia berada di New York. Pertemuannya dengan para pakar dari berbagai bidang ilmu itu telah melahirkan berbagai konsep yang sangat penting dalam membentuk teori budaya yang sangat unik itu. Dikatakan sangat unik karena memang belum terpikirkan oleh para pakar di bidang antropologi sebelumnya.

Levi-Strauss dilahirkan pada 28 November 1905 di Brussels, Belgia. Ia adalah keturunan Yahudi. Ayahnya bernama Raymond LeviStrauss, seorang artis dan juga anggota keluarga Yahudi Perancis yang terpelajar. Sedangkan ibunya bernama Emma Levy.

Minat utama Levi-Strauss sebenarnya adalah ilmu hukum. Ia mempelajari hukum di fakultas hukum Paris pada tahun 1927. Di tahun yang sama ia juga mempelajari filsafat di Universitas Sorbonne. Ia pernah sukses dalam bidang hukum ketika ia mendapatkan lisensi dalam bidang hukum. Penguasaan dalam bidang hukum mengenai aliran-aliran filsafat materialisme historis ini turut mendorong kesuksesannya dalam bidang antropologi. Hal yang paling penting dan sangat berpengaruh terhadap loyalitasnya di bidang antropologi adalah ketika ia membaca buku Primitive Society yang ditulis oleh Robert Lowie. Buku itu cukup mengesankan bagi Levi-Strauss dan mendorongnya untuk mengadakan beberapa studi mengenai masyarakat primitif. Bahkan ia menjadi bosan mengajar di Mont de-Marsan Lycee dan ber- 
keinginan untuk mengadakan perjalanan keliling dunia.

Apa yang diharapkan oleh Levi-Strauss ini akhirnya terkabul setelah ia berkesempatan menjadi pengajar di Universitas Sao Paulo, Brazil. Di universitas ini ia memiliki kesempatan untuk berkeliling ke daerah-daerah pedalaman Brazil, serta mengunjungi berbagai suku Indian yang pada masa itu boleh dikatakan belum terjamah oleh peradaban Barat. Dari ekpedisi yang didukung oleh Musee de 1'Hummed dan museum di kota Sao Paulo ini ia berkesempatan untuk mempelajari orang-orang Indian Caduveo dan Bororo. Pengalaman perjalanannya menjelajah daerah-daerah terpencil itu ditulisnya dalam sebuah buku yang berjudul Tristes Tropique. Buku ini bercerita tentang penderitaan orang-orang Indian di belantara Amazone. Berawal dari buku inilah yang menjadikan Levi-Strauss terkenal sampai ke negara asalnya, Prancis. Ia bahkan telah menghasilkan suatu karya yang sangat penting di bidang antropologi yang sesungguhnya sangat jauh dari studi formal yang dimilikinya.

Karir Levi-Strauss sempat mengalami hambatan saat ia harus menjalani wajib militer. Ia ditugaskan di bagian pos telekomunikasi di bidang sensor telegram. Sampai akhirnya ia diangkat menjadi liaison officer, yaitu petugas penghubung. Namun situasi seperti itu tidak menghalangi dirinya untuk menjadi seorang profesor. Ia akhirnya dibebaskan dari kewajiban militer setelah menjadi seorang profesor. Halangan tidak hanya sampai di situ, ia juga mengalami diskriminasi ras. Ia dipecat dari jabatannya karena ia adalah seorang Yahudi. Akhirnya Levi-Strauss diselamatkan oleh program Yayasan Rockefeller yang memiliki program menyelamatkan ilmuwan dan pemikir-pemikir Eropa berdarah Yahudi di Amerika Serikat. Dari program ini Levi-Strauss berhasil datang ke New York dan selamat dari pembantaian tentara Nazi yang anti-Yahudi. Di daerah Greenwich Village Levi-Strauss tinggal. Di kota New York inilah Levi-Strauss semakin banyak memiliki peluang mengembangkan keilmuannya. Ia banyak berkomunikasi dengan para ilmuwan buangan dari Prancis, seperti Maz Ernst, Franz Boas, Ruth Benedict, A.L. Kroever dan Ralph Linton. Ia pun berkesempatan mengajar mata kuliah etnologi di New York Ecole Libre des Hautes 
Etudes, yang didirikan oleh para intelektual pelarian dari Prancis.

Menurut Levi-Strauss, ada alasan kuat untuk menyetarakan kekerabatan dengan obyek linguistik. Baginya kekerabatan dapat dianggap sebagai semacam bahasa sebab aturan-aturan yang diikuti klen-klen primitif di bidang kekerabatan dan perkawinan memang merupakan suatu sistem. Sistem-sistem itu terdiri atas relasi-relasi dan oposisi-oposisi, seperti; suami-istri, bapak-anak, saudara lelaki-saudara perempuan (Bertens, 2001: 197). Dengan menerapkan metode strukturalistis dalam penyelidikan relasi-relasi kekerabatan, ia berusaha untuk menemukan aturan-aturan atau sistem tertentu yang berlaku dalam suatu kelompok atau klen.

Dalam penyelidikannya, Levi-Strauss juga menemukan adanya titik singgung lain antara bahasa dan kekerabatan. Sama seperti bahasa, kekerabatan pun merupakan suatu sistem komunikasi. Bahasa adalah sistem komunikasi karena informasi atau pesan-pesan disampaikan oleh suatu individu kepada individu lain. Kekerabatan pun adalah sistem komunikasi, karena klen-klen, famili-famili atau grup-grup saling menukar wanita-wanita mereka. Sebagaimana bahasa, kekerabatan pun merupakan pertukaran komunikasi, dialog (Bertens, 2001:198). Oleh karena bahasa dan kekerabatan dapat dianggap sebagai dua fenomen yang dapat disetarakan, maka keduanya dapat diselidiki menurut metode yang sama, yaitu metode strukturalistis. Hal lain yang menyebabkan kekerabatan dapat disetarakan dengan bahasa, menurut LeviStrauss, adalah tentang ketidaksadaran. Sama seperti bahasa, sistem kekerabatan pun dikuasai oleh unsur-unsur atau aturan-aturan yang tidak disadari.

Untuk membandingkan kesamaan antara sistem kekerabatan dengan sistem bahasa, Levi-Strauss mengatakan:

"... marriage regulations and kinship systems as a kind of language, a set of process permitting the establishment between individuals and groups of a certain type of communication. That the mediating factor, in this case, should be the women of the group, who are circulated between clans, lineages, or families, in place of the words of the group, which are circulated between individuals, does 
not at all change the fact that the essential aspect of the phenomenon is identical in both cases" (Sperber, 1979:23).

(... aturan-aturan perkawinan dan sistem kekerabatan sebagai satu jenis bahasa, (adalah) seperangkat proses yang mengizinkan pembentukan di antara individu-individu dan kelompok-kelompok dari suatu jenis komunikasi tertentu. Bahwa faktor penghubung, dalam kasus ini, adalah para wanita dari kelompok itu yang dipertukarkan di antara klen-klen, keturunan-keturunan, keluarga-keluarga, sebagai pengganti kata-kata dari kelompok itu, yang dipertukarkan antara individu-individu, sepenuhnya tidak mengubah kenyataan bahwa aspek esensial dari fenomena tersebut adalah sama dalam kedua kasus).

\section{SISTEM KEKERABATAN MINANGKABAU}

Sistem kekerabatan pada masyarakat hukum adat Minangkabau oleh para ahli hukum lazim disimpulkan dalam kata-kata rumusan/ rumusan kata-kata matrilineal, genologis dan teritorial. Pada sistem kekerabatan matrilineal ini garis keturunan adalah dari ibu dan wanita: anak-anaknya hanya mengenal ibu dan saudarasaudara ibunya; ayah dan keluarganya tidak masuk clan anaknya karena ayah termasuk clan ibunya pula.

Para ahli antropologi sependapat bahwa garis-garis keturunan matrilineal merupakan yang tertua dari bentuk garis keturunan lainnya. Salah seorang dari ahli tersebut bernama Wilken yang terkenal dengan teori evolusinya. Wilken mengemukakan proses dari garis keturunan ini pada masa pertumbuhannya adalah sebagai berikut: (1) Garis keturunan ibu; (2) Garis keturunan ayah; (3) Garis keturunan orangtua (Amir, 2006: 8-9). Menurut teori evolusi, garis keturunan ibu dianggap yang tertua dan kemudian garis keturunan ayah. Selanjutnya si anak tidak hanya mengenal garis keturunan ibunya, tetapi juga garis keturunan ayahnya. Alasan yang digunakan oleh penganut teori evolusi ini menitikberatkan terhadap evolusi kehidupan manusia.

Pada masa lalu pergaulan antara laki-laki dan wanita masih be- 
bas, belum mengenal norma-norma perkawinan. Untuk memudahkan silsilah seorang anak dengan berdasarkan kelahiran, berdasarkan alam yang terkembang menjadi guru, dalam kenyataan, yang beranak itu adalah wanita atau betina. Dengan demikian, keturunan berdasarkan perempuan adalah yang mendapat tempat pertama. Dalam kenyataan sampai saat ini, masyarakat Minangkabau masih bertahan dengan garis keturunan ibu dan tidak mengalami evolusi. Di samping itu, garis keturunan ibu di Minangkabau erat kaitannya dengan sistem kewarisan sako dan pusako. Seandainya garis keturunan mengalami perubahan maka akan terjadi suatu perubahan dari sendi-sendi adat Minangkabau sendiri. Oleh karena itu, bagi orang Minangkabau garis keturunan bukan hanya sekedar menentukan garis keturunan anak-anaknya melainkan erat sekali hubungannya dengan adatnya.

Banyak ahli Barat menulis tentang Minangkabau yang ada kaitannya dengan sistem kekerabatan Minangkabau. Salah seorang dari para ahli tersebut adalah Branislaw Malinowsky yang mengemukakan sebagai berikut:

1) Keturunan dihitung menurut garis ibu.

2) Suku dibentuk menurut garis ibu.

3) Pembalasan dendam merupakan tata kewajiban bagi seluruh suku.

4) Kekuasaan di dalam suku, menurut teori terletak di tangan ibu tetapijarang dipergunakan.

5) Tiap-tiap orang diharuskan kawin dengan orang luar suku.

6) Yang sebenarnya berkuasa adalah saudara laki-lakinya.

7) Perkawinan bersifat matrilokal, yaitu suami mengunjungi rumah istri (Rauda, 2004: 217).

Pembahasan di atas, yang tidak ditemui sekarang adalah pembalasan dendam yang merupakan tata kewajiban seluruh suku, mungkin itu terjadi pada masa dahulu. Selanjutnya akan dibicarakan sistem kekerabatan matrilineal di Minangkabau.

\section{Garis kekerabatan dan kelompok-kelompok masyarakat}

Garis keturunan dan kelompok-kelompok masyarakat yang 
menjadi inti dari sistem kekerabatan matrilineal di Minangkabau ini adalah paruik. Setelah Islam masuk ke Minangkabau, hal itu disebut kaum. Kelompok sosial lainnya yang merupakan pecahan dari paruik adalah jurai. Interaksi sosial yang terjadi antar orang, atau seseorang dengan kelompoknya, secara umum dapat dilihat pada sebuah kaum. Dahulu, mereka pada mulanya tinggal dalam sebuah rumah gadang. Bahkan pada masa dahulu didiami oleh berpuluh-puluh orang. Ikatan batin sesama anggota kaum besar sekali dan hal ini bukan hanya didasarkan atas pertalian darah saja, tetapi juga di luar faktor tersebut. Secara garis besar faktor-faktor yang mengikat kaum ini adalah sebagai berikut.

1) Orang sekaum seketurunan

Walaupun di Minangkabau ada anggapan orang yang sesuku juga bertali darah, namun bila diperhatikan betul asal-usul keturunannya agak sulit dibuktikan. Lain halnya dengan orang yang sekaum, walaupun orang yang sekaum itu sudah puluhan orang dan bahkan sampai ratusan, namun untuk membuktikan mereka seketurunan masih bisa dicari. Untuk menguji silsilah keturunan mereka, dari ranji dapat dilihat generasi mereka sebelumnya dan sampai sekarang, yang ditarik dari garis keturunan wanita. Faktor keturunan sangat erat hubungannya dengan harta pusaka dari kaum tersebut. Ranji yang tidak jelas atau tidak ada sama sekali bisa menyebabkan kericuhan mengenai harta pusaka kaum tersebut dan juga mengenai sako.

2) Orang yang sekaum sehina semalu

Anggota yang berbuat melanggar adat akan mencemarkan nama seluruh anggota kaum, dan yang paling terpukul adalah mamak kaum dan kepala waris yang diangkat sebagai pemimpin kaum. Karena perasaan sehina semalu cukup mendalam, maka seluruh anggota selalu diajak agar jangan terjadi hal-hal yang tidak diharapkan dari anggota kaum. Mengenai rasa sehina semalu ini, adat mengatakan: malu tak dapek dibagi, suku tak dapek dianjak (malu tak dapat dibagi, suku tidak dapat dianjak). Artinya, malu satu orang adalah malu 
bersama. Mamak atau wanita-wanita yang sudah dewasa selalu mengawasi rumah gadangnya agar tidak terjadi hal-hal yang tidak diinginkan.

3) Orang yang sekaum sepandam sepekuburan

Untuk menunjukkan orang itu sekaum, maka sebuah kaum mempunyai pandam tempat berkubur khusus bagi anggota kaumnya. Barangkali ada yang perlu dibicarakan berkaitan dengan pandam ini. Di Minangkabau terdapat beberapa istilah untuk tempat memakamkan mayat, seperti pandam, pekuburan, ustano dan jirek. Kuburan ini merupakan tempat kuburan umum dan di sini tidak berlaku seketurunan dan siapa saja atau mamak mana asalnya tidak jadi soal.

4) Orang yang sekaum seberat seringan

Orang yang sekaum seberat seringan, sesakit sesenang sebagian, dikemukakan dalam adat "kaba baik baimbauan, kaba buruk bahambauan" (kabar baik dihimbaukan, kabar buruk berhamburan). Artinya bila ada sesuatu yang baik untuk dilaksanakan, seperti perkawinan, berdoa dan lain-lain, maka kepada sanak saudara hendaklah diberitahukan agar mereka datang untuk menghadiri acara yang akan dilaksanakan. Tetapi sebaliknya semua sanak famili akan berdatangan jika mendengarkan kabar buruk dari salah seorang anggota keluarganya tanpa dihimbau, sebagai contohnya seperti ada kematian atau malapetaka lain yang menimpa.

5) Orang yang sekaum seharta sepusaka

Menurut adat Minangkabau, tidak dikenal harta perseorangan. Harta merupakan warisan dari anggota kaum secara turun-temurun. Harta pusaka yang banyak dari sebuah kaum menunjukkanjuga bahwa nenek moyangnya merupakan orang asal di kampung itu sebagai peneruka pertama, dan kaum yang sedikit mempunyai harta pusaka bisa dianggap orang yang datang kemudian. Oleh sebab itu di dalam adat sebuah kaum yang memiliki banyak harta tetapi hasil tembilang emas atau dengan cara membeli, maka statusnya dalam masyarakat adat tidak sama dengan orang yang mempunyai harta 
pusaka tinggi. Justru orang yang seperti ini disebut sebagai orang pendatang.

Harta pusaka kaum merupakan kunci yang kokoh sebagai alat pemersatu dan tetap berpegang kepada prinsip harato salingka kaum, adat salingka nagari (harta selingkar kaum, adat selingkar nagari). Selanjutnya garis kekerabatan yang berkaitan dengan kaum ini adalah jurai. Sebuah kaum merupakan kumpulan dari jurai dan tiap jurai tidak sama jumlah anggotanya. Setiap jurai membuat rumah gadang pula, tetapi rumah gadang asal tetap dipelihara bersama sebagai rumah pusaka kaum. Pimpinan tiap jurai ini disebut tungganai atau mamak rumah sebuah anggotajurai.

Pecahan dari jurai disebut samande (seibu), yaitu ibu dengan anakanaknya, sedangkan suami atau orang sumando tidak termasuk orang samande. Orang yang samande diberi ganggam bauntuk, pagang bamasieng (genggam yang sudah diperuntukkan, dan masing-masing sudah diberi pegangan). Artinya, masing-masing orang yang samande telah ada bagian harta pusaka milik kaum. Bagi mereka hanya diberi hak untuk memungut hasil dan tidak boleh menggadaikan, apalagi menjual bila tidak semufakat dengan anggota kaum.

\section{Perkawinan}

Berdasarkan adat Minangkabau tidak dibenarkan orang yang sekaum melakukan perkawinan meskipun mereka sudah berkembang menjadi ratusan orang. Walaupun agama Islam sudah merupakan anutan bagi masyarakat Minangkabau, namun kawin sesama anggota kaum masih dilarang oleh adat. Hal ini mengingat keselamatan hubungan sosial dan kerusakan turunan (Amir, 2006: 10). Demikian pula bila terjadi perkawinan sesama anggota kaum, itu mempunyai akibat terhadap harta pusaka dan sistem kekerabatan matrilineal. Oleh karena itu, sampai sekarang perkawinan masih tetap dilakukan dengan orang di luar sukunya (exogami). Perkawinan merupakan inisiasi ke alam baru bagi seorang manusia dan merupakan perubahan dari tingkat umur, seperti masa bayi ke kanak-kanak, dari kanak-kanak ke alam dewasa dan kemudian kejenjang perkawinan. 
Beberapa hal yang perlu dikemukakan yang berkaitan dengan perkawinan ini adalah sebagai berikut:

1) Inisiatif datang dari pihak keluarga perempuan

Pada masa lalu seorang mamak akan merasa malu bila kemenakannya, yang menurut ukuran masyarakat sudah sepantasnya untuk kawin, belum juga mendapat jodoh. Ia malu bila dikatakan kemenakannya gadih gadang alun balaki (gadis besar belum bersuami). Pada masa lalu dibenarkan untuk menggadaikan harta pusaka tinggi bila terdapat gadih gadang alun balaki. Segala upaya dilakukan demi memperoleh jodoh bagi kemenakan. Mencari calon suami untuk kemenakan dikatakan juga mencari junjungan untuk tempat kemenakannya menyadarkan diri. Hal ini juga tidak terlepas dari alam takambang jadi guru, ibarat kacang panjang membutuhkan junjungan untuk membelitkan dirinya.

Lazimnya pada masa lalu si gadis tidak ditanya terlebih dahulu apakah ia mau kawin atau tidak, atau calon suaminya disukai atau tidak. Hal ini karena seseorang yang belum kawin masih dianggap belum dewasa. Apalagi pada masa lalu seorang wanita sudah dicarikan suami dalam umur yang relatif muda, seperti umur 13, 14 atau 15 tahun. Bila sudah menjanda baru ditanya pendapatnya karena ia dianggap sudah matang untuk melakukan pilihan.

Dalam masyarakat Minangkabau pada masa lalu inisiatif untuk mengawinkan anak kemenakan datang dari pihak keluarga perempuan sesuai dengan sistem keibuan yang dipakai. Datuk atau mamaknya atau keduanya pada suatu waktu yang baik dan dalam suasana yang tenang dan resmi mengajak ayah gadis tersebut berunding dan bertanya, apakah sudah terlintas dalam pikirannya seorang laki-laki yang layak untuk diminta menjadi menantunya. Dapat disimpulkan antara mamak dengan ayah kemenakannya melakukan pendekatan terlebih dahulu. Setelah itu baru dibawa kepada anggota kaum untuk dirundingkan atau dilakukan musyawarah bersama. Dalam hal ini urang sumando mengajukan calonnya pula. Setelah dapat kata sepakat barulah diutus utusan untuk menjajaki 
keluarga laki-laki yang diharapkan menjadi calon junjungan kemenakannya.

Perkawinan yang dilakukan atas musyawarah seluruh anggota kaum dan antara dua kaum sangat diharapkan dalam adat, karena pada akhirnya bukan hanya mempertemukan seorang gadis dengan seorang laki-laki, melainkan mempertemukan dua keluarga besar. Seandainya terjadi hal yang tidak diinginkan, seperti pertengkaran suami istri, perceraian dan lain-lain, maka seluruh anggota keluarga merasa bertanggung jawab untuk menyelesaikannya dan menanggung segala resikonya.

Pada saat ini mungkin saja calon suami atau istri datang dari pihak gadis atau laki-laki, namun jalur adat harus diikuti juga. Segala permasalahan tentang calon suami/isteri dibawa kepada mamak atau kaum keluarga sehingga nilai-nilai adat tetap terpelihara. Sangat tercela bila pemuda mencari jodoh sendiri dan melangsungkan perkawinan sendiri tanpa melibatkan masing-masing anggota keluarga.

2) Calon menantu yang diidamkan

Pada umumnya orang Minangkabau pada masa lalu dalam mencari calon menantu mempunyai ukuran-ukuran tertentu atau syarat-syarat/tata nilai yang berlaku pada waktu itu. Yang paling disukai adalah urang babangso (orang berbangsa). Orang ini dalam keluarga laki-laki mamaknya adalah pemangku adat atau penghulu yang disegani dalam masyarakat adat. Mendapat calon menantu yang merupakan pemangku adat dan berpredikat datuk serta baik budi agar keturunannya nanti menjadi anak orang terpandang, dan soal pekerjaan atau jaminan ekonomi tidak dipermasalahkan. Setelah Islam masuk ke Minangkabau calon menantu yang diinginkan adalah orang yang alim serta taat beragama. Kesemuanya itu tidak lain untuk menambah martabat bagi seseorang dan anggota kaum pada umumnya.

Namun pada saat ini terjadi perubahan sistem nilai, yakni kecenderungan mencari calon menantu yaitu orang yang penuh tanggung jawab dan mempunyai pekerjaan tetap, meskipun segi ketaat- 
an beragama dan budi yang baik tetap menjadi pertimbangan. Dahulu soal ekonomi dari calon menantu kurang dipertimbangkan, bukan berarti pihak suami tidak bertanggung jawab, melainkan pada waktu itu hasil harta pusaka sawah dan ladang sudah memadai. Tentu penduduk belum sebanyak sekarang jika dibandingkan dengan harta pusaka yang ada.

3) Kecenderungan Mencari Menantu dari Hubungan Keluarga Terdekat

Merupakan ciri khas juga pada masa lalu calon suami atau istri dicarikan dari hubungan keluarga terdekat, seperti pulang kebako, atau pulang ke anak mamak. Hal ini tidak lain agar hubungan keluarga itu jangan sampai putus dan berkesinambungan pada generasi selanjutnya. Secara tersirat ada juga alasan agar harta pusaka dapat dimanfaatkan bersama antara anak dan kemenakan. Hubungan perkawinan keluarga terdekat ini dalam adat dikatakan juga kuah tatumpah ka nasi, siriah pulang ka gagangnyo (kuah tertumpah ke nasi, sirih pulang ke gagangnya).

Pada masa lalu perkawinan dalam lingkungan dekat sangat diharuskan. Bila terjadi seorang laki-laki kawin di luar nagarinya akan diberi sanksi dalam pergaulan masyarakat adat. Tujuan lain adalah untuk memperkokoh hubungan kekerabatan sesama warga nagari. Sangat tidak disenangi bila seorang pemuda yang berhasil dalam kehidupannya tiba-tiba kawin dengan orang dari luar kampung atau nagarinya. Hal ini dikatakan ibarat mamaga karambia condong, buahnyo jatuah kaparak urang (memagari kelapa condong, buahnya jatuh ke kebun orang). Keberhasilan seseorang dianggap tidak terlepas dari peranan anggota kaum, kampung dan nagari. Oleh sebab itu, sudah sepantasnya jangan orang lain yang mendapat untungnya.

4) Setelah Perkawinan Suami Tinggal di Rumah Isteri

Berkaitan dengan sistem kekerabatan matrilineal, setelah perkawinan suami tinggal di rumah istri (dalam istilah antropologi budaya disebut matrilokal). Pada zaman dahulu suami pulang ke rumah istrinya pada sore hari dan subuhnya kembali ke rumah 
orangtuanya. Hal ini mungkin terjadi bila terjadi dalam lingkungan daerah yang masih kecil, seperti sekampung, senagari asalkan tidak bersamaan suku. Namun sejak dahulu sampai sekarang orang Minangkabau tetap mengatakan bahwa suami tinggal di rumah istri bila berlangsung perkawinan.

5) Tali Kekerabatan Setelah Perkawinan

Sebagai akibat dari hasil perkawinan adalah timbulnya tali-tali kerabat antara keluarga istri dengan keluarga rumah gadang suami atau sebaliknya. Tali kerabat itu seperti tali induak bako anak pisang, tali kerabat sumando dan pasumandan, tali kerabat ipar, besan dan menantu (Putiah, 2004: 312-316).

Bagi orang Minangkabau menantu dibedakan atas dua bagian. Pertama, menantu sepanjang syarak. Maksudnya, bagi seorang mamak beserta istri dan saudara laki-lakinya, istri/suami anaknya merupakan menantu sepanjang syarak. Yang kedua, menantu sepanjang adat. Maksudnya, bagi seorang mamak beserta istri dan saudara laki-lakinya, istri/suami kemenakan merupakan menantu sepanjang adat.

6) Sumando yang diidamkan

Nilai seorang sumando sekaligus merupakan nilai seorang mamak di luar lingkungan sosial rumah gadang, karena orang sumando tersebut adalah juga seorang mamak di rumah gadangnya. Sampai sejauh mana tingkah laku seorang sumando dalam melakukan perannya, orang Minangkabau mengklasifikasikannya sebagai berikut(Diradjo, 2009: 263-266):

a) Sumando bapak paja atau sumando ayam gadang (ayam besar). Maksudnya orang sumando hanya pandai beranak saja seperti ayam besar, sedangkan tanggung jawab kepada anak istrinya tidak ada.

b) Sumando langau hijau (lalat hijau). Penampilan gagah dan meyakinkan tetapi perangai tidak baik. Suka kawin cerai dengan meninggalkan anak. Seperti langau hijau suka hinggap di mana-mana dan kemudian terbang meninggalkan bangan (kotoran).

c) Sumando kacang miang. Orang sumando kacang miang punya pera- 
ngai yang suka memecah-belah kaum keluarga istrinya, seperti kacang miang yang membuat orang gatal-gatal.

d) Sumando lapiak buruak (tikar buruk). Sumando lapiak buruak (tikar buruk) orang sumando seperti ini tidak menjadi perhitungan di tengah-tengah kaum istrinya. Ibarat tikar buruk hanya dipakai kalau betul-betul diperlukan, kalau tidak perlu, tikar buruk ini tidak digunakan.

e) Sumando kutu dapua. Sumando seperti ini banyak di rumah daripada di luar, suka melakukan pekerjaan yang hanya pantas dilakukan oleh wanita, seperti memasak, mencuci piring, menumbuk lada, menggendong anak dan lain-lain.

f) Sumando ninik mamak. Sumando ninik mamak adalah sumando yang diharapkan oleh keluarga istrinya. Sumando ninik mamak di rumah gadang istrinya akan bersikap nan tahu dikieh kato sampai mengampuangkan nan taserak, mangamehi nan tacicia (tahu dengan kias kata sampai mengapungkan yang terserak, mengemasi yang tercecer). Maksudnya halus budi bahasanya, suka membantu $k a-$ um keluarga istrinya, baik secara moril maupun materiil. Demikian pula di rumah gadang kaumnya ia berfungsi mauleh mano nan putuih, senteng mambilai, kurang manukuak (mangulas mana yang putus, senteng menyambung, kurang menambah). Dengan pengertian dia suka turun tangan dan cepat tanggap menyelesaikan segala persoalan dalam anggota kaumnya.

Dengan adanya pengklasifikasian orang sumando ini, bagi orang Minangkabau sendiri, terutama bagi laki-laki, akan dapat berpikir jenis manakah yang akan dipakainya seandainya dia kawin dan menjadi sumando di rumah istrinya.

\section{Peranan Ibu dan Bapak dalam Keluarga}

Perkawinan tidak menciptakan keluarga inti (nuclear family) yang baru, sebab suami atau istri tetap menjadi anggota dari garis keturunan masing-masing. Oleh karena itu, pengertian keluarga inti yang terdiri dari ibu, ayah, dan anak-anak sebagai suatu unit yang tersendiri tidak terdapat dalam struktur sosial Minangkabau. Yang dimaksud dengan 
keluarga dalam struktur sosial masyarakat Minangkabau adalah paruik yang terdiri dari individu-individu yang dikemukakan di atas. Dalam proses sosialisasi seorang individu dalam rumah gadang banyak ditentukan oleh peranan ibu dan mamak. Sedangkan ayahnya lebih berperan di tengah-tengah paruiknya pula.

Pengertian ibu dalam hal ini bukan berarti ibu dari anak-anaknya, melainkan sebagai sebutan dari semua wanita yang sudah berkeluarga dalam sebuah rumah gadang. Sedangkan untuk wanita keseluruhan orang Minangkabau menyebut 'perempuan'. Perempuan berasal dari kata Sansekerta, yaitu empu yang berarti dihormati. Begitu dihormati perempuan Minangkabau dapat dilihat pada garis keturunan yang ditarik dari garis ibu, rumah tempat kediaman diperuntukkan bagi wanita, hasil sawah ladang juga untuk wanita dan lain-lain. Peranan seorang ibu sangat besar sekali. Semasa seseorang masih bayi, orang yang dikenal pertama kali hanya ibunya dan saudaranya seibu. Dia mencintai ibunya sebagai orang yang mengasuh dan memberinya makan. Ia, ibunya dan saudara-saudaranya merupakan suatu kelompok yang terasing dari orang-orang di luar kelompok. Bila terjadi sesuatu hal terhadap ibunya atau saudara-saudaranya dia akan berpihak kepadanya.

Setelah menanjak dewasa mulai diadakan pemisahan antara pemuda dan gadis. Bagi anak laki-laki tidak dibenarkan lagi tinggal di rumah gadang, ia dengan teman-teman sebaya tidur di surau atau di rumah pembujangan. Proses sosialisasi selanjutnya banyak diperoleh di surau ini, karena di surau bukan hanya para pemuda dan remaja saja yang tinggal, tetapi juga anggota keluarga laki-laki yang sekaum dengannya dan belum kawin atau menduda, dan umumnya sudah dewasa. Surau adalah tempat mengaji, tempat belajar adat-istiadat dan tempat mendengar kisah-kisah lama yang bersumber dari tambo alam Minangkabau. Adakalanya sebelum tidur mereka juga belajar pencak silat sebagai ilmu bela diri untuk membekali dirinya, baik untuk di kampung maupun persiapan untuk pergi ke rantau nantinya. Proses sosialisasi anak laki-laki menuju remaja dan dewasa banyak ditentukan oleh peranan mamak-mamaknya dalam rumah gadang.

Anak-anak perempuan yang meningkat gadis selalu berada di samping ibunya dan perempuan-perempuan yang sudah dewasa di 
dalam rumah gadang. Dia diajar memasak membantu ibunya di dapur, dan mengurus rumah tangga. Di samping itu juga diajar menjahit, dan menyulam, serta semua kepandaian yang dibutuhkan dalam mempersiapkan diri berumah tangga nantinya.

Dalam sistem keturunan matrilineal, ayah bukanlah anggota dari garis keturunan anak-anaknya. Dia dipandang sebagai tamu dan diperlakukan sebagai tamu dalam keluarga, yang tujuannya terutama memberi keturunan. Seorang suami di rumah gadang istrinya adalah seorang sumando. Namun demikian, bukanlah berarti laki-laki tersebut hilang kemerdekaannya. Ia tetap merdeka seperti sebelum kawin, dan ia boleh beristri dua, tiga atau sampai empat, tanpa dapat dihalangi oleh istrinya. Dia boleh menceraikan istrinya jika dia atau keluarganya tidak senang dengan kelakuan istrinya. Sebaliknya istri dapat pula meminta cerai dari suaminya jika dia tidak cinta lagi kepada suaminya, atau jika pihak keluarganya tidak senang melihat kelakuan menantunya atau kelakuan salah seorang keluarga menantunya.

Bila diperhatikan, ungkapan-ungkapan adat memperlihatkan bahwa seorang ayah atau seorang sumando di dalam kaum istrinya tidak mempunyai kekuasaan apa-apa dalam keluarga istrinya, termasuk terhadap anak-anaknya, sebagaimana dikatakan "sedalam-dalam payo, sahinggo dado itiak, saelok-elok urang sumando sahingga pintu biliak" (sedalam-dalam payau, hanya sampai dada itik, sebaik-baik orang semenda hanya sampai pintu bilik). Demikian pula dikatakan, orang sumando ibarat abu di ateh tunggua (abu di atas tunggul), datang angin berterbangan. Ada beberapa hal yang mendukung mengapa peranan ayah begitu kecil sekali terhadap anak/ istri, dan kaum keluarga istrinya waktu itu. Kehidupan waktu itu masih bersifat rural agraris, yaitu kehidupan petani sebagai sumber penghidupan. Penduduk masih jarang, harta masih luas, dan memungkinkan seorang ayah tidak perlu memikirkan kehidupan sosial ekonominya. Di samping itu seorang ayah tidak perlu memikirkan tentang pendidikan anak-anaknya beserta biayanya, karena sekolah formal waktu itu tidak ada. Secara tradisional seorang anak meniru pekerjaan mamaknya.

Bila mamaknya bertani maka kemenakannya dibawa pula bertani. Jika mamaknya berdagang maka kemenakannya dibawa pula untuk 
membantunya. Kawin cerai tidak menjadi persoalan, yang penting keturunan dan martabat dari ayahnya. Demikian pula anak-anak perempuan, pendidikannya hanya terbatas dalam lingkungan rumah gadang saja, dan proses pendidikan lebih banyak diarahkan kepada persiapan untuk menempuh jenjang perkawinan. Di samping itu karena interaksi dengan dunia luar belum ada sehingga kemungkinan untuk mengubah pola struktur yang telah ada sedikit sekali. Barangkali bagi orang Minangkabau sekarang kurang tepat bila memandang masa lalu dengan kacamata sekarang, karena ruang lingkup waktu dan tempat yang berbeda.

Dalam proses selanjutnya, terjadi perubahan peranan ayah terhadap anak dan istrinya karena berbagai faktor sesuai dengan perkembangan sejarah. Munculnya keinginan merantau dari orang Minangkabau, masuknya pengaruh Islam dan pendidikan modern telah membawa perubahan-perubahan cara berpikir dalam hidup berkeluarga dan dalam tanggung jawab terhadap anak istrinya.

Bagi yang pergi merantau dia melihat struktur sosial yang berbeda dari masyarakat kampung yang ditinggalkan selama ini. Bisa jadi ia melihat betapa akrabnya hubungan suami-istri beserta anak-anaknya yang tinggal dalam satu rumah. Membawa istri ke daerah rantau dan hidup bersama dengan anak-anak merupakan sejarah baru yang selama ini tidak pernah ditemui. Hidup yang bebas dengan anak-anaknya dalam rumah sendiri telah membawa gema ke kampung halaman. Bila mendapat rezeki di rantau, si ayah membuatkan rumah untuk anak istrinya di kampung untuk membuktikan keberhasilannya di rantau. Rumah yang didirikan walaupun masih di tanah kaum istrinya, tetapi sudah berpisah dari rumah gadang.

Pergeseran peranan mamak kepada ayah dipercepat lagi setelah mantapnya agama Islam menjadi anutan masyarakat Minangkabau. Agama Islam secara tegas menyatakan bahwa kepala keluarga adalah ayah. Dalam permulaan abad ke-19 pengaruh Barat, terutama melalui jalur pendidikan, ikut juga memperkuat kedudukan dan peranan ayah di tengah-tengah anak istrinya. Namun demikian, itu bukan berarti bergesernya sistem kekerabatan matrilineal kepada patrilineal.

Ayah dan kedudukannya sebagai seorang mamak tetap diharap- 
kan oleh kemenakan sebagai pembimbing, sesuatu yang dibutuhkan oleh kemenakannya. Meskipun tidak sepenuhnya dapat dilakukan seperti kedudukan anak dalam keluarga yang langsung setiap hari di bawah lindungan dan bimbingan orangtuanya. Meskipun kemenakan itu sebenarnya sebagai anak pada orangtuanya akan sama pula keadaannya sebagaimana bapak-bapak yang lain mempertanggungjawabkan anaknya.

\section{KEKERABATAN MINANGKABAU MENURUT STRUKTURALISME LEVI-STRAUSS}

Kekerabatan Minangkabau berdasarkan sistem kekerabatan Strukturalisme Levi-Strauss berkaitan erat dengan masalah yang terdapat dalam antropologi, yaitu tentang incest. Hampir dalam semua kebudayaan ditemukan adanya incest atau larangan. Dalam hal ini Levi-Strauss melihat bahwa larangan melakukan perkawinan antara sesama klen atau kelompok tidak dapat hanya dilihat dari segi biologis saja, yaitu ketakutan akan adanya penyakit turunan bila seseorang kawin dengan anggota kelompoknya. Baginya pertukaran merupakan semacam "hukum alam" bagi kehidupan sosial. Berdasarkan pandangan Levi-Strauss ini, kebudayaan Minangkabau melarang adanya perkawinan satu suku (klen). Perkawinan antar satu suku di Minangkabau merupakan aib yang akan membuat malu suku atau klen tersebut. Perkawinan antar satu suku sangat ditabukan, meskipun kedua belah pihak berasal dari desa yang berbeda.

Pertukaran (saling menukar wanita antar kelompok) sebagai "hukum alam" disamakan oleh Levi-Strauss dengan "hukum alam" pada planet-planet. Jika planet-planet melanggar hukum alam, maka ia akan hancur. Demikian juga dengan larangan kawin antara sesama klen, jika larangan kawin sesama klen itu dilanggar, maka masyarakat akan hancur berantakan. Jadi ada proses tidak sadar yang menguasai manusia yang berasal dari suatu aktivitas tak sadar dari psyche manusiawi.

Dalam usaha menganalisis segala macam sistem kekerabatan, Levi-Strauss berpangkal kepada keluarga inti (Levi-Strauss, 1969: 50). 
Ketiga macam hubungan dalam keluarga inti adalah: (1) hubungan antara seorang individu E dengan saudara-saudara sekandungnya yang berupa hubungan darah; (2) hubungan antara E dengan isterinya yang berupa hubungan karena kawin, yang menghubungkan kelompok saudara sekandungnya sendiri dengan saudara sekandung isterinya; (3) hubungan yang lain adalah hubungan antara E dan isterinya dengan anak-anak mereka, yang berupa hubungan keturunan, (LeviStrauss, 1969: 41). Hubungan antara saudara sekandung dan hubungan karena perkawinan ada dua macam, yang menurut Levi-Strauss secara universal selalu bertentangan kebutuhan. Seorang individu biasanya akan bersikap positif dalam hubungannya dengan saudara sekandungnya, tetapi negatif dalam hubungannya dengan iparnya. Dalam kenyataan, kehidupan kekerabatan yang oleh Levi-Strauss dianggap hubungan positif adalah hubungan berdasarkan sikap bersahabat, mesra, dan cinta-mencintai, sedangkan apa yang dianggapnya hubungan negatif adalah hubungan berdasarkan sikap sungkan, resmi dan menghormat.

Untuk jelasnya di antara kasus etnografi yang dipergunakan Levi-Strauss, misalnya mengenai keluarga inti dalam masyarakat penduduk kepulauan Trobiand, yang mempunyai sistem keturunan yang matrilineal. Hubungan antara suami dan isteri adalah sangat hangat dan mesra, dan berdasarkan sikap saling mencintai; jadi menurut LeviStrauss, positif. Sebaliknya, hubungan antara saudara pria dan wanita terkekang oleh berbagai pantangan dan suatu adat sopan santun pergaulan yang ketat dan resmi.

Levi-Strauss (1969: 119) mengatakan ada empat syarat model agar terbentuk struktur sosial, yaitu:

1) Sebuah struktur menawarkan sebuah karakter sistem. Struktur terdiri atas elemen-elemen seperti sebuah modifikasi apa saja, yang salah satunya akan menyeret modifikasi seluruh elemen lainnya.

2) Seluruh model termasuk dalam sebuah kelompok transformasi, di mana masing-masing berhubungan dengan sebuah model dari keluarga yang sama, sehingga seluruh transformasi ini membentuk sekelompok model. 
3) Sifat-sifat yang telah ditunjukkan sebelumnya tadi memungkinkan untuk memprakirakan dengan cara apa model akan beraksi menyangkut modifikasi salah satu dari sekian elemennya.

4) Model itu harus dibangun dengan cara sedemikian rupa sehingga keberfungsiannya bisa bertanggung jawab atas semua kejadian yang diobservasi.

Kebudayaan Minangkabau secara turun-temurun telah menegaskan bahwa suku atau klen merupakan komunitas yang satu meskipun berlainan desa atau daerahnya. Laki-laki adalah pihak yang datang ke pihak perempuan, sistem ini berbeda dengan kekerabatan patrilineal pada umumnya yang menempatkan perempuan yang datang ke pihak laki-laki. Keluarga inti menurut kebudayaan Minangkabau diatur berdasarkan garis keturunan ibu. Ibu sebagai pusat kekerabatan itu dalam kebudayaan Minangkabau disebut dengan Bundo Kanduang.

Hubungan kekerabatan dalam kebudayaan Minangkabau sebagai akibat dari adanya perkawinan akan melahirkan hubungan sebagai berikut:

1) Tali kerabat induak bako anakpisang, yaitu hubungan kekerabatan antara seseorang dengan saudara-saudara perempuan bapaknya, atau hubungan seorang perempuan dengan anak-anak saudara laki-lakinya. Saudara-saudara perempuan dari seorang bapak adalah induak bako dari anak-anaknya. Sedangkan anak-anak dari seorang bapak merupakan anak pisang dari saudara-saudara perempuan bapaknya. Anak-anak perempuan dari saudara-saudara perempuan bapak adalah "bakonya".

2) Tali kekerabatan sumando dan pasumandan. Dengan adanya perkawinan maka terjadi hubungan sumando pasumandan. Bagi seluruh anggota rumah gadang istri, suaminya menjadi urang sumando (orang semenda) seseorang istri bagi keluarga suaminya menjadi pasumandan.

3) Sumando berasal dari bahasa sansekerta yaitu sandra, sedangkan dalam bahasa Minangkabau menjadi sando dengan sisipan um menjadi sumando. Persamaan kata sando adalah gadai. Dalam kehidupan sehari-hari ada istilah pegang gadai. Bagi pihak yang menerima 
jaminan berupa benda harta yang digadaikan disebut sando, sedangkan orang yang memberikan hartanya sebagai jaminan dikatakan menggadaikan. Demikianlah sebagai penerima dari keluarga perempuan terhadap seorang menjadi suami anak kemenakannya dikatakan sebagai sumando. Namun demikian jangan diartikan secara negatif seperti terjadinya pegang gadai dalam kehidupan seharihari.

4) Seorang istri yang menjadi pasumandan dari anggota rumah gadang suaminya dia berperan sebagai komunikator antara suaminya dengan tungganai dan mamak rumah gadangnya. Sedang untuk mengkomunikasikan kepentingan sendiri sebagai istri, biasanya melalui saudara-saudara perempuan suami.

5) Tali kekerabatan ipar, bisan dan menantu. Bagi seorang suami, saudara-saudara perempuan istrinya menjadi bisannya. Sedangkan saudara-saudara laki-laki dari istrinya adalah menjadi iparnya. Sebaliknya, saudara-saudara perempuan suaminya merupakan bisannya, dan saudara laki-laki suaminya menjadi iparnya. Dalam kehidupan sehari-hari orang Minangkabau menyebut ipar, bisan ini "ipa bisan" dan kadang-kadang disambung saja jadi "pabisan".

\section{SIMPULAN}

Berbeda dari sistem kekerabatan patrilineal yang dianut oleh sebagian besar kebudayaan dunia yang menjadikan wanita sebagai sarana komunikasi antarklen atau suku, kebudayaan Minangkabau yang menganut sistem matrilineal justru menjadikan laki-laki sebagai sarana komunikasi antar klen atau suku. Inisiatif perjodohan dalam perkawinan menurut adat Minangkabau datang dari pihak perempuan untuk melamar pihak laki-laki. Mamak pihak laki-laki akan melakukan penjajakan dengan mamak pihak perempuan untuk menjodohkan kedua kemenakan mereka.

Berdasarkan sistem kekerabatan matrilineal yang dianut oleh kebudayaan Minangkabau, laki-laki adalah pihak yang datang ke rumah pihak perempuan yang disebut sebagai urang sumando. Berdasarkan 
sistem matrilineal kebudayaan Minangkabau, ada larangan untuk mengawini orang yang satu suku. Perkawinan dalam satu suku dilarang berdasarkan adat Minangkabau. Perkawinan sesama suku merupakan incest yang harus dihindari, meskipun itu terjadi antara suku yang sudah berbeda nagari (desa).

\section{DAFTAR PUSTAKA}

Amir, M.S., 2006, Adat Minangkabau: Pola dan Tujuan Hidup Orang Minang, PT. Mutiara Sumber Media, Jakarta.

Bertens, K., 2001, Filsafat Barat Kontemporer, PT. Gramedia Pustaka Utama, Jakarta.

Diradjo, I, Dt., S., 2009, Tambo Alam Minangkabau, Kristal Multimedia, Bukittinggi.

Kurzwell, E., 1980, The Age of Structuralism, Columbia University Press New York.

Levi-Strauss, C., 1969, The Elementary Structures of Kinship, Translated from the French by James Harle Bell, John Richard von Sturmer and Rodney Needham, Beacon Press, Boston.

Mudhofir, Ali, 1988, Kamus Teori dan Aliran Dalam Filsafat, Liberty, Yogyakarta.

Putiah, H.J. Dt. Malako Nan, 2004, “Matrilinial Dalam Adat Minangkabau" dalam Ch. N. Latif, Minangkabau Yang Gelisah: Mencari Strategi Sosialisasi Pewarisan Adat dan Budaya Minangkabau untuk Generasi Muda, CV. Lubuk Agung, Bandung.

Rauda, P. R., 2004, "Sistem Matrilinial dalam Adat dan Budaya Minangkabau", dalam Ch. N. Latif, Minangkabau Yang Gelisah: Mencari Strategi Sosialisasi Pewarisan Adat dan Budaya Minangkabau untuk Generasi Muda, CV. Lubuk Agung, Bandung.

Schiwy, G., 1986, "Structuralism" dalam Karl rahner (ed.), Sacramentum Mundi, Vol. 6, Burns \& Oates, London.

Sperber, D., 1979, “Claude Levi-Strauss, dalam John Sturrock (ed.) Structuralism and Since from Levi-Strauss to Derrida, Oxford University Press, Oxford.

Wittig, S. (ed.), 1975, Structuralism; An Interdisciplinary Study, The Pickwick Press, Pittsburgh, Pennsylvania. 